\title{
Prevalence of Puccinia abrupta var. partheniicola and its impact on Parthenium hysterophorus in Kathmandu Valley, Nepal
}

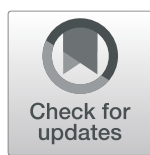

\author{
Seerjana Maharjan ${ }^{1,2^{*}}$ D. Anjana Devkota ${ }^{1}$, Bharat Babu Shrestha', Chitra Bahadur Baniya', \\ Muniappan Rangaswamy ${ }^{3}$ and Pramod Kumar Jha ${ }^{1 *}$
}

\begin{abstract}
Background: Parthenium hysterophorus is a noxious invasive weed in tropical and subtropical regions of the world, including Nepal. Among 11 species of biological control agents released to control P. hysterophorus in Ausrtalia, winter rust Puccina abrupta var. partheniicola arrived fortuitously and has established in Kathmandu Valley, Nepal, nearly a decade back. However, the prevalence and effectiveness of this rust as a biological control agent in Kathmandu remain unknown. To address this knowledge gap, a roadside survey was done at an interval of $2 \pm 0.25 \mathrm{~km}$ in Kathmandu Valley to assess the $P$. abrupta var. partheniicola incidence and its impacts on $P$. hysterophorus. Infested individuals of $P$. hysterophorus were further divided into four severity classes (very low, low, medium, and high), and rust incidence was calculated. The impact of the winter rust on the growth of $P$. hysterophorus was assessed by comparing biomass and seed output of infested and non-infested individuals.
\end{abstract}

Results: Among 81 locations where P. hysterophorus was present in the Kathmandu Valley, winter rust infestation was observed at 98\% locations. At some locations within Kathmandu Valley such as Tinkune, Kirtipur, Chabahil, Buddha Chowk, and Dhobighat, the impacts of the rust on P. hysterophorus were medium to high. Aboveground biomass and seed output of $P$. hysterophorus were reduced by $47 \%$ and $73 \%$, respectively, due to winter rust infestation. The study indicates that winter rust incidence is widespread in Kathmandu Valley with very low to high levels of damages to $P$. hysterophorus depending on the localities.

Conclusion: The rust has, therefore, a potential to reduce the growth performance of $P$. hysterophorus, and it can be used as a component of integrated management of $P$. hysterophorus by introducing to other suitable areas in Nepal.

Keywords: Parthenium weed, Winter rust, Biocontrol, Disease incidence, Disease severity

\section{Background}

The biological control of invasive species using fungal pathogens can be a cost-effective and sustainable tool for reducing the negative impacts of invasive alien plant species in an ecosystem as these pathogens are highly host-specific (McFadyen 1998; Charudattan and Dinoor 2000; Seastedt 2015). There are several records of successful biocontrol methods using fungal pathogens in

\footnotetext{
*Correspondence: seerjana9@hotmail.com; pkjhaprof@gmail.com

${ }^{1}$ Central Department of Botany, Tribhuvan University, Kathmandu, Nepal

Full list of author information is available at the end of the article
}

many countries around the world, especially with rust fungi (Charudattan 2001).

Parthenium hysterophorus L. (hereafter referred to as parthenium weed) has been recognized as a major invasive weed in tropical and subtropical regions of the world since the mid-1970s with severe impacts on natural and agricultural ecosystems and human and animal health (Adkins et al. 2019). It is an annual herbaceous plant and has invaded 49 countries across the world (Adkins et al. 2019; Maharjan et al. 2020). Biological control of parthenium weed was initiated in Australia in 1976 and now has been continued to other parts of the

(c) The Author(s). 2020 Open Access This article is licensed under a Creative Commons Attribution 4.0 International License, which permits use, sharing, adaptation, distribution and reproduction in any medium or format, as long as you give appropriate credit to the original author(s) and the source, provide a link to the Creative Commons licence, and indicate if changes were made. The images or other third party material in this article are included in the article's Creative Commons licence, unless indicated otherwise in a credit line to the material. If material is not included in the article's Creative Commons licence and your intended use is not permitted by statutory regulation or exceeds the permitted use, you will need to obtain permission directly from the copyright holder. To view a copy of this licence, visit http://creativecommons.org/licenses/by/4.0/ 
world including India, Pakistan, South Africa, Ethiopia, Tanzania, and Uganda (Strathie et al. 2011; Dhileepan et al. 2019; Maharjan et al. 2020). The winter rust Puccinia abrupta var. partheniicola (H. S. Jackson) Parmelle (hereafter referred to as winter rust), a native of Argentina, Bolivia, Brazil, and Central America, is a potential biocontrol agent among 11 agents identified for the control of parthenium weed (Evans 1997; Dhileepan and McFadyen 2012; Dhileepan et al. 2019). The host range of the winter rust tested against many plant species indicated the rust to be sufficiently host-specific for the consideration as a biological control agent of parthenium weed, and the rust caused a significant decrease in vegetative growth and seed production of parthenium weed (Evans 1987; Parker et al. 1994; Fauzi 2009). With the first introduction as a potential biological control agent for parthenium weed in Australia in 1990, the winter rust has been reported from various countries including Mauritius, India, Kenya, China, Ethiopia, South Africa, Nepal, Tanzania, and Pakistan with no deliberate release (Parker et al. 1994; Dhileepan and Strathie 2009; Shrestha 2012; Iqbal et al. 2020). It forms brown powdery pustules on the upper leaf surface, stem, and inflorescences (Parker et al. 1994) (Fig. 1). There is a report of significant damage in parthenium weed by winter rust in Ethiopia and Pakistan (Taye 2002; Iqbal et al. 2020).

Like in other parts of the world, the rapid expansion of parthenium weed in Nepal has reduced species richness and altered species composition in grassland ecosystems (Timsina et al. 2011; Shrestha et al. 2015). In Nepal, winter rust was not deliberately introduced and was reported for the first time from Kathmandu Valley (Kirtipur municipality) in 2011 as a second biological control agent for parthenium weed after Zygogramma bicolorata L. (Shrestha 2012). Except for the reporting of its occurrence in Nepal, no further study has been conducted to investigate the prevalence and impact of this rust on parthenium weed in Nepal. Therefore, the main objective of the present study was to document the distribution of winter rust in Kathmandu Valley, assess the severity of the infestation, and analyze its impact on parthenium weed in Kathmandu Valley. The present study could potentially contribute to a management plan for parthenium weed in Nepal.
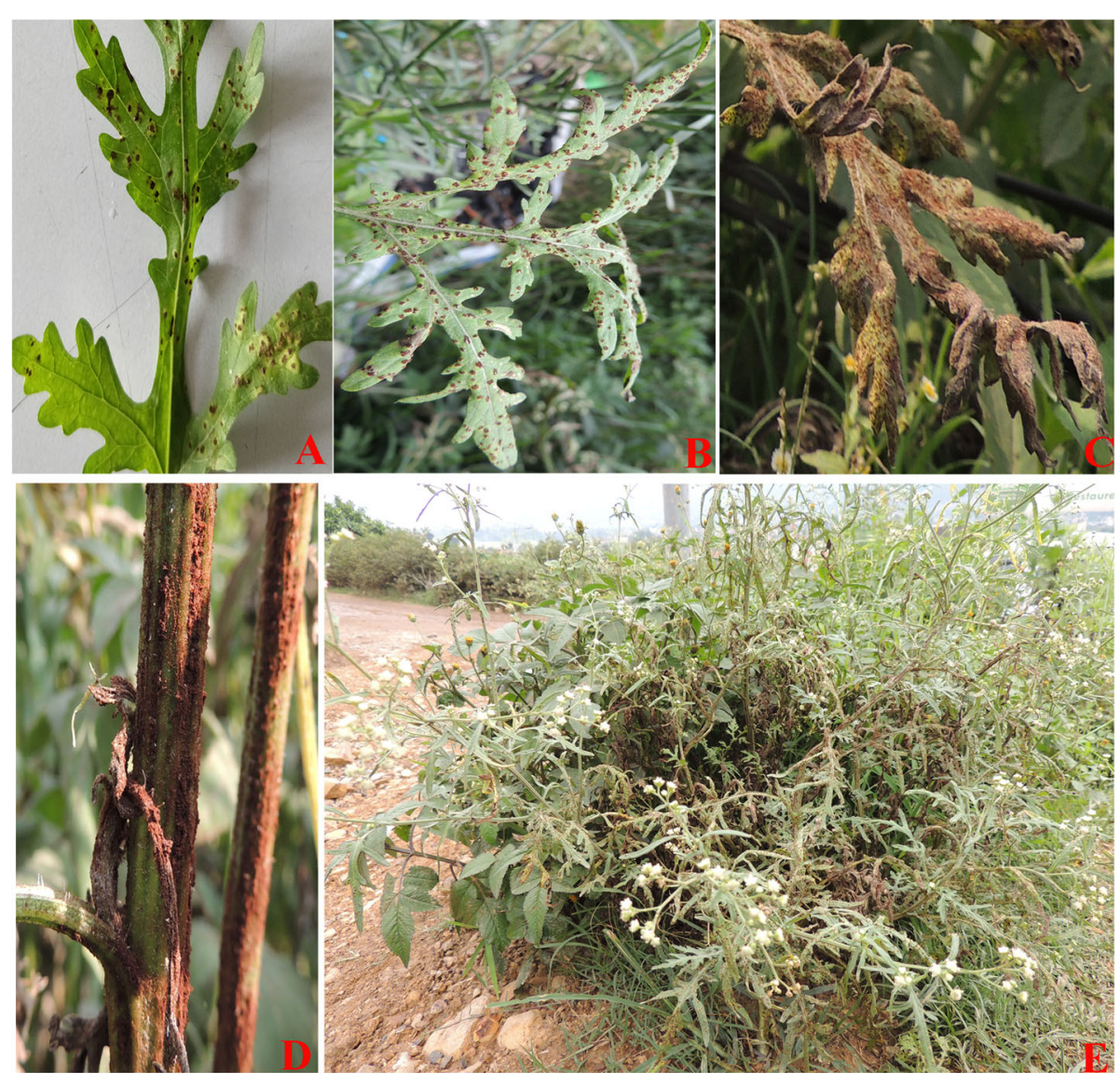

Fig. 1 Young pustules of Puccinia abrupta var. partheniicola with visible chlorosis on the leaves of Parthenium hysterophorus (a), rust pustules spreading on the upper surface of the leaf (b), ruptured rust pustules with curling on the leaf (c), infestation on the stem surface (d), and habit of infected $P$. hysterophorus with deformed growth (e) 


\section{Materials and methods}

\section{Study area}

The study was conducted in Kathmandu Valley $\left(27^{\circ}\right.$ $31^{\prime}-27^{\circ} 49^{\prime} \mathrm{N}$ latitudes and $85^{\circ} 11^{\prime}-85^{\circ} 34^{\prime} \mathrm{E}$ longitude, 1250 to 1730 masl.) along the road networks (Fig. 2) during June 2019. It represents the most urbanized area of Nepal with three major cities-Kathmandu, Bhaktapur, and Lalitpur (Adhikari et al. 2012). It has a sub-tropical climate with $19-27^{\circ} \mathrm{C}$ temperature in summer and 2$20^{\circ} \mathrm{C}$ temperature in winter and an annual average rainfall of $1400 \mathrm{~mm}$ (Pant and Dangol 2009). The major roadside vegetation in the study area included Bidens pilosa L., Cynodon dactylon (L.) Pers., Amaranthus spinosus L., Alternanthera sessilis (L.) DC., Conyza sp., Galinsoga sp., Solanum nigrum L., Solanum xanthocarpum Schard. \& Wendl., Xanthium sp., Kyllinga brevifolia Rottb., Oxalis corniculata L., and Fimbristylis dochotoma (L.) Vahl.

\section{Distribution mapping}

The survey was done at an interval of $2 \pm 0.25 \mathrm{~km}$ (using scooter speedometer) along the roadsides of Kathmandu Valley except when there was no parthenium weed
(Table S1). In the case of the absence of parthenium weed at the above interval, the survey was continued in a nearby available location. A rectangle quadrat of size 2 $\times 1 \mathrm{~m}^{2}$ was sampled at each location to count the number of plants. In each quadrat, a total number of infested and healthy individuals of parthenium weed were counted. Infested individuals of parthenium weed were further divided into five different severity classes (Table 1 , Fig. S1). The identity of winter rust on parthenium weed was identified and confirmed by symptoms and microscopic observations following the description provided by Parmelee (1967) (Fig. S2).

The infestation by winter rust into parthenium weed at various locations of Kathmandu Valley was presented in the map by interpolating rust incidence percentage value in ArcGIS using geostatistical wizard tool (French et al. 2011).

\section{Impact assessment}

Among all the locations surveyed, three sites (Kirtipur-

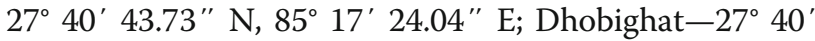

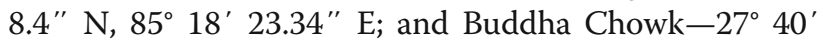
$\left.52.62^{\prime \prime} \mathrm{N}, 85^{\circ} 14^{\prime} 40.4^{\prime \prime} \mathrm{E}\right)$ with comparatively higher

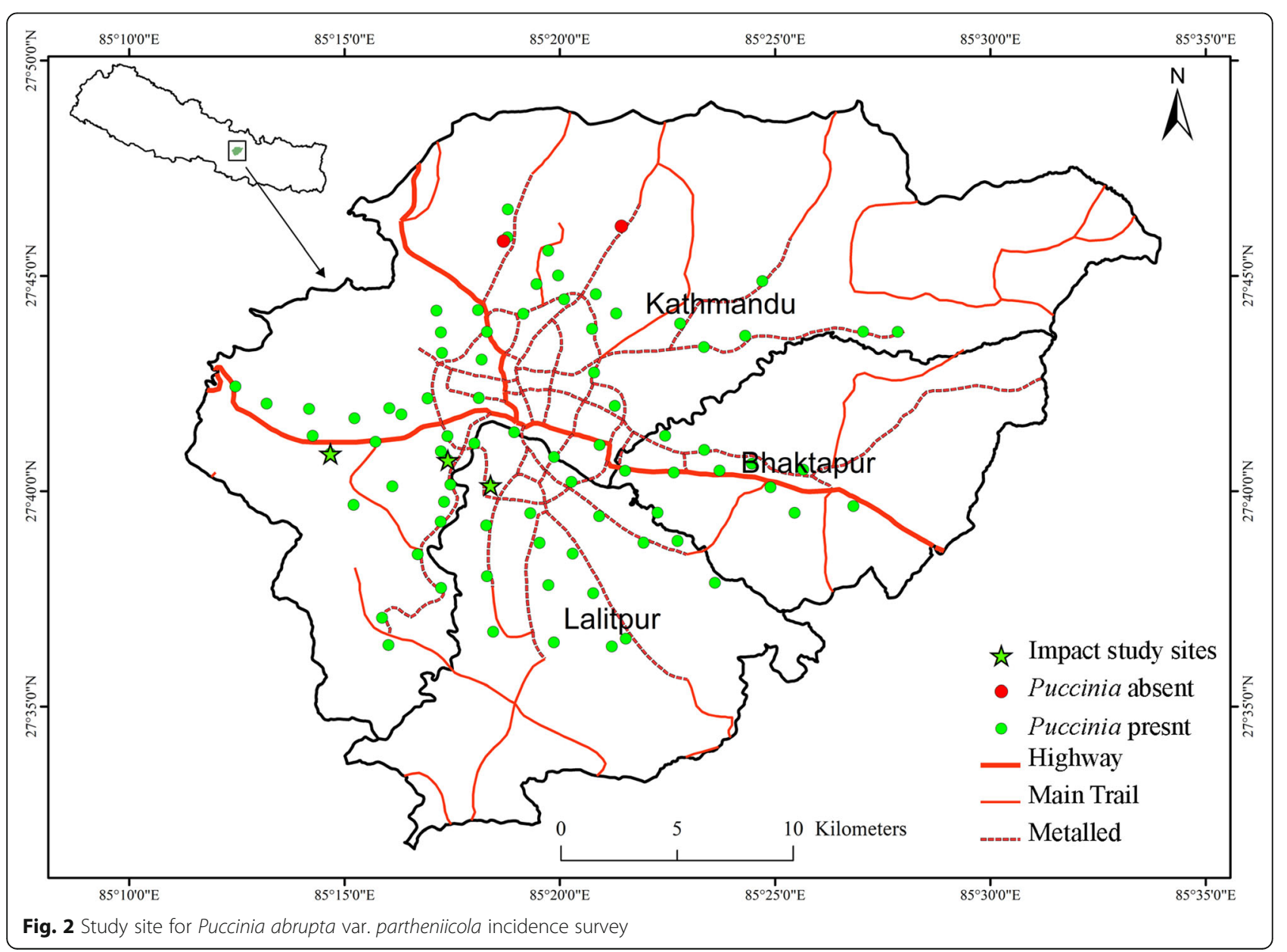


Table 1 Categorization of infested Parthenium hysterophorus individuals based on the severity of infestation by winter rust

\begin{tabular}{lll}
\hline SN & Severity class & Description of severity class \\
\hline 1 & No & Healthy plant with no infestation \\
2 & Very low & Only a few leaves infested without any apparent impact on growth \\
3 & Low & Premature senescence of some leaves but not apparent impact on inflorescence \\
4 & Medium & Death of about $50 \%$ of leaves with apparent impacts on inflorescence but not senescence of plant \\
5 & High & Death or senescence of plant \\
\hline
\end{tabular}

levels of infestation by winter rust were selected for impact studies (Fig. 2). At each location, three plots of $5 \times$ $5 \mathrm{~m}^{2}$ were selected for sampling. From each plot, 10 healthy individuals and 10 infested individuals (medium severity class with deformed growth) having similar basal diameters were sampled. The number of flowers present in each plant was counted. The total seed output of each individual was calculated, assuming that a single flower produces five achenes (Adkins and Shabbir 2014). The aboveground portion of each individual was packed in a paper bag and oven-dried at $70{ }^{\circ} \mathrm{C}$ for $48 \mathrm{~h}$. Then, the biomass was measured by using a digital balance with an accuracy of $0.001 \mathrm{~g}$.

\section{Data analysis}

Rust incidence was calculated by using the following formula (Bekeko et al. 2012):

$$
\text { Rust incidence }(\%)=\frac{\text { Total number of plants infested }}{\text { Total number of plants inside the plot }} \times 100
$$

The normality (Shapiro-Wilk test) and homogeneity of variance (Leven's test) for all the parameters were tested prior to choosing a parametric or non-parametric tool to analyze. The data did not meet the assumption of normality and homogeneity of variance. Hence, significant differences between variation in biomass and number of seeds among infested and non-infested individuals were tested by non-parametric Mann-Whitney-Wilcoxon test. The analyses were carried out using the $\mathrm{R}$ program, and all figures were also drawn in $\mathrm{R}$ program version 3.6.1 (R Core Team 2019).

\section{Results}

The infected leaves of parthenium weed were noted as light brown pustules on the adaxial surface (Fig. 1b). Brown pustules were even observed in the stem on severely infected plants affecting the growth of the plant. Chlorosis and curling of the leaves were also distinctly visible in highly infested conditions (Fig. 1a, c).

A total of 136 locations were surveyed inside Kathmandu Valley, of which parthenium weed was present in $81(60 \%)$ locations. Winter rust infestation was observed in all of the locations (98\% locations out of 81) where parthenium weed was present except at Phutung and Budhanilkantha (Fig. 2). The infestation of winter rust on parthenium weed individuals was seen in most of the locations, but the severity of infestation was very low with few leaves infested and no visible impact on the growth of parthenium weed (Fig. 3). In contrast, at some locations (Tinkune, Kirtipur, Chabahil, Buddha Chowk, Dhobighat, Airport), the impact on most of the individuals of parthenium weed was very visible with severity of infestation medium to high, affecting the growth of the plant. The interpolation of the rust incidence value of various locations into the map indicated that the rust incidence was higher in the central core area of Kathmandu Valley (Fig. 4).

There was a significant impact of winter rust infestation on the aboveground biomass and total seed output of parthenium weed (Fig. 5a, b). The infestation reduced biomass and seed output by $47 \%$ and $73 \%$, respectively.

\section{Discussion}

The absence of winter rust infestation at only two locations out of 81 surveyed locations indicates that the rust is widespread and still tending to spread in Kathmandu Valley. In Nepal, the rust was first reported from Kirtipur in 2011 during which the impact of rust on the plant was marginal (Shrestha 2012). Since then, the incidence of the rust at some locations around Kirtipur has been observed with very minimal damage to parthenium weed (Shrestha et al. 2015). Higher rust incidence in the central core area of Kathmandu Valley might be because of the first establishment of the rust in Kirtipur, and it is still tending to spread in the valley.

Low temperature and moisture present on the surface of the leaves of the host plant is the major factor determining the existence of winter rust while higher temperature reduces the extent of infection on parthenium weed (Parker et al. 1994; Taye 2002). And, in more humid, lowland regions, winter rust infestation does not affect the growth of parthenium weed (Evans 1987). There is a report of a low to high level of rust incidence depending upon the site conditions and season in the experimental sites of South Africa, too (Strathie et al. 2016). The higher rust incidence in the central core region of Kathmandu Valley during mid-July is an indication of widespread of the rust from the initial reported place, i.e., Kirtipur, and the rust might have received favorable environmental conditions for its growth. 


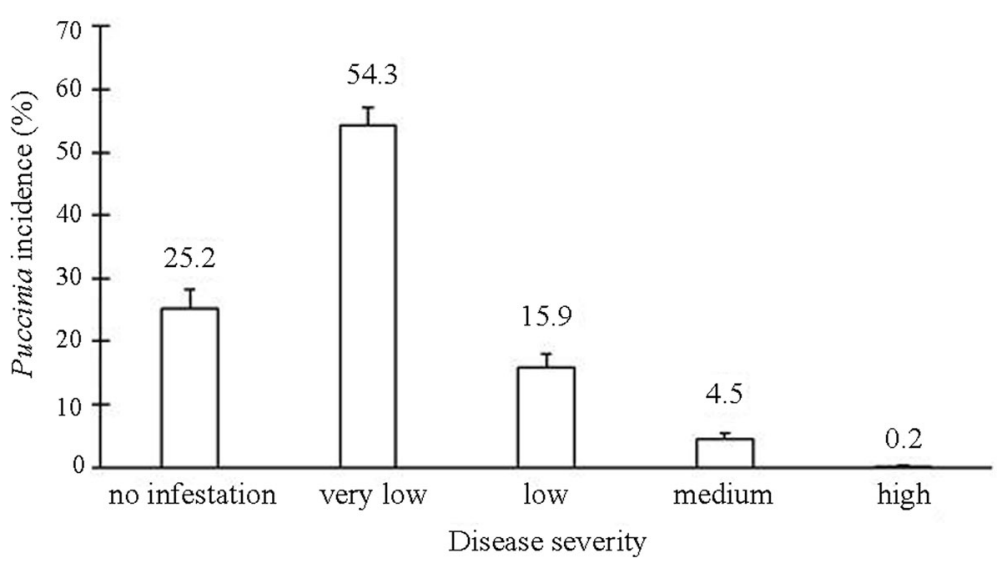

Fig. 3 Degree of infestation in Parthenium hysterophorus individuals by Puccinia abrupta var. partheniicola in Kathmandu Valley

Winter rust infestation includes premature senescence of the leaves to senesce, reducing the life expectancy and flower production up to $40 \%$ and $90 \%$, respectively (Parker et al. 1994). Taye et al. (2002) reported the reduction in the seed production in parthenium weed by $42 \%$ due to the rust in Ethiopia. The present study showed the average reduction in the seed production by $73 \%$. Winter rust infestation accelerates the senescence of the leaves of parthenium weed and reduces the amount of photosynthate products which lead to reduce the biomass, the length of flowering shoots, and the number of flowers (Parker et al. 1994). The production of a lesser number of flowers ultimately reduces seed production and restricts the spread of the weed to some extent. In addition, infested plants would be susceptible to stress and become less competitive to the other associated plants (Parker et al. 1994).

Within 8 years since its first report, the rust has shown its widespread distribution in Kathmandu Valley with a significant visible impact on parthenium weed under a natural environment. There is also a report of winter rust outside Kathmandu Valley from Trishuli and Gorkha districts of Nepal (pers. Obs. of BB Shrestha in April to May 2019), indicating favorable environmental conditions for the growth of the rust in other parts of Nepal, too. However, the level of damage to the weed by the rust has to be studied further in those areas.

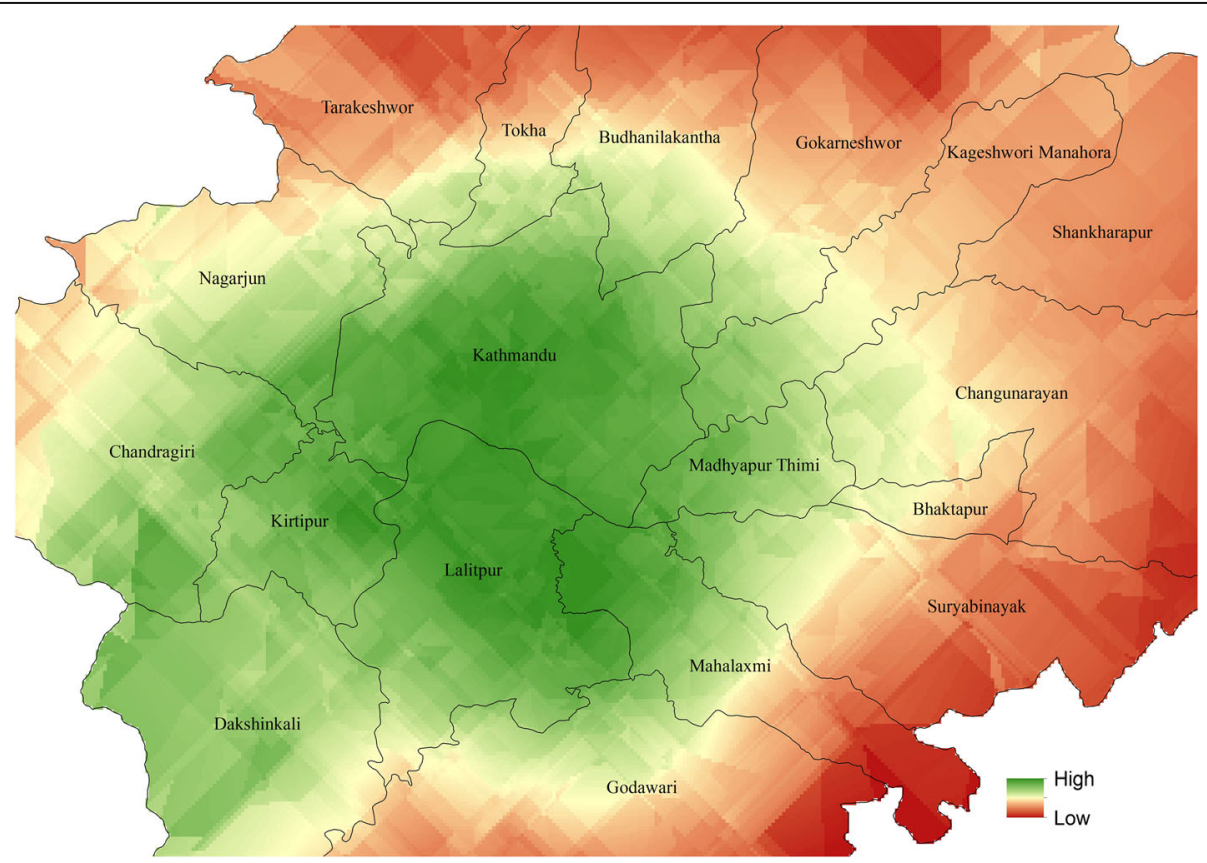

Fig. 4 Map showing Puccinia abrupta var. partheniicola incidence in various locations of Kathmandu Valley 


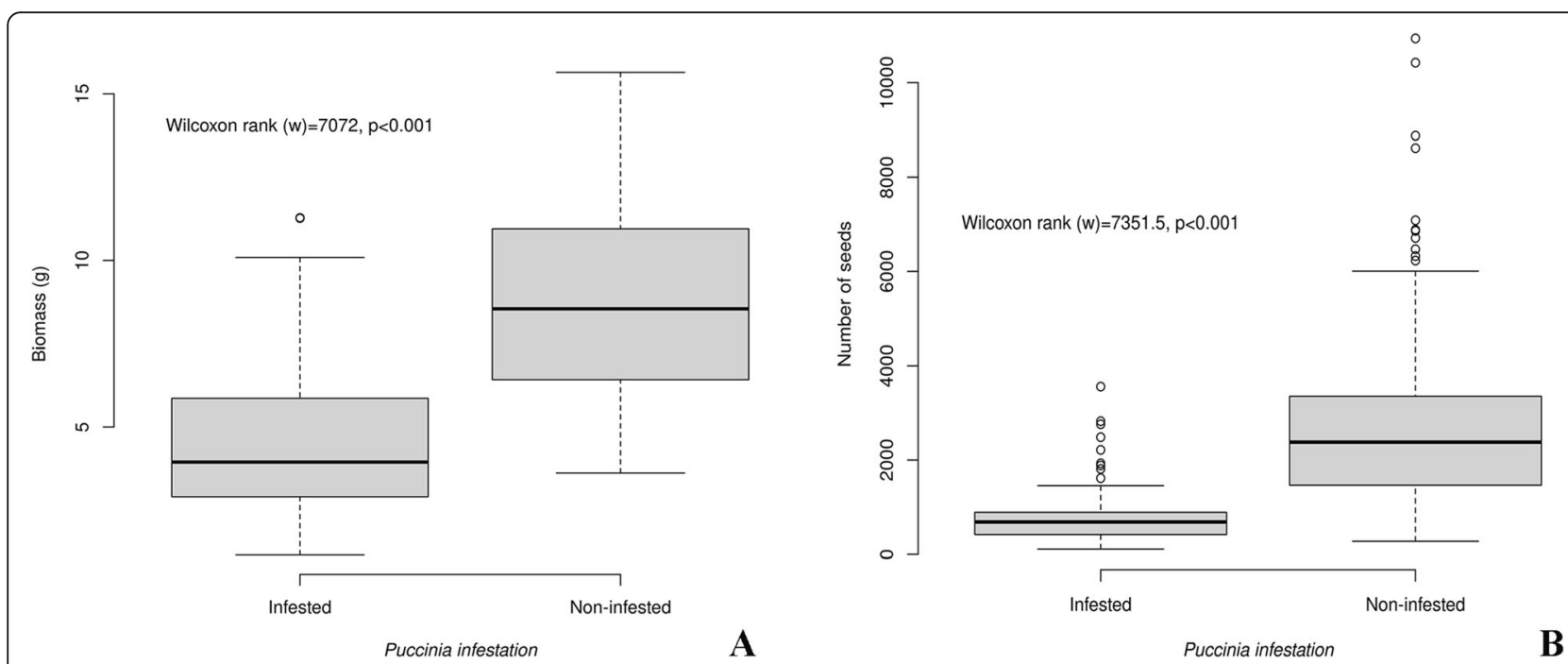

Fig. 5 Impact of Puccinia abrupta var. partheniicola on aboveground biomass (a) and seed output (b) of Parthenium hysterophorus

Winter rust is an autoecious, macrocyclic rust that completes its life cycle only on parthenium weed and grows well in cool, mid-altitude $(1500-2500 \mathrm{~m})$ regions where the rainfall varies from 700 to $1400 \mathrm{~mm}$ with frequent frost and night temperatures are close to the optimum temperature (below $20^{\circ} \mathrm{C}$ ) (Parker et al. 1994; Taye 2002). During April to May, the night temperature of Kathmandu Valley is between 12 and $15{ }^{\circ} \mathrm{C}$, and it is close to the optimal temperature required for the proliferation of spores of winter rust and with the start of the rainy season, i.e., at the end of June during which the minimum temperature is above $18{ }^{\circ} \mathrm{C}$, the rust gradually starts to disappear from the plant (Shrestha 2012; DHM 2016). The growth and seed production of parthenium weed inside Kathmandu Valley peaks during the rainy months, i.e., August to September (Pokhrel 2013). Hence, the disappearance of winter rust during the weed's peak growing season could only have minimal impact on the growth of parthenium weed. However, the rust can weaken the plant and reduce seed production before the rainy season (Parker et al. 1994). Thus, it can be effective as a complementary biological control agent for parthenium weed during winter and early summer when another promising biological control agent, Zygogramma bicolorata, remains quiescent in countries like Nepal, where the weed is seen at various stages throughout the year.

As parthenium weed reproduces by seed, reduced seed production likely reduces the spread of the weed and reduces competitiveness to the crop and other native plant species (Taye 2002). One of the advantages of winter rust infestation to plants is that it has the capacity to infest all green parts of plants with rapid multiplication within 8 days (Evans 1987; Parker et al. 1994). Though the rust does not kill the host completely, the present findings as well as studies by Fauzi (2009) have also shown that it can significantly reduce the biomass and seed production of parthenium weed. So, it would appear to be a promising biological control agent in mid-altitude (> $1000 \mathrm{~m}$ ) regions of Nepal. In addition, the introduction of winter rust to other climatically suitable parts of Nepal where parthenium weed is highly problematic could be done to control the weed to some extent.

\section{Conclusion}

The results showed that Puccinia abrupta var. partheniicola has spread across Kathmandu Valley with a significant reduction in biomass and seed production of Parthenium hysterophorus at some localities. It can partially control $P$. hysterophorus during winter and early summer when another biological control agent, Zygogramma bicolorata, remains inactive. The identification of climatically suitable regions outside Kathmandu Valley and subsequent release of this rust in such areas can be a part of the integrated management of parthenium weed in Nepal.

\section{Supplementary information}

Supplementary information accompanies this paper at https://doi.org/10. 1186/s41610-020-00168-5.

\footnotetext{
Additional file 1: Table S1. Total Survey sites showing total number of plants infested by Puccinia abrupta var. partheniicola and rust incidence in different locations of Kathmandu Valley. Fig. S1. Photographs of Parthenium hysterophorus infested by Puccinia abrupta var. partheniicola in different severity classes ( $\mathrm{A}$ - healthy plant with no infestation; B - only a few leaves infested without any apparent impact on growth; $C$ premature senescence of some leaves but not apparent impact on inflorescence; D - death of about $50 \%$ leaves with apparent impacts on inflorescence but not senescence of plant; $E$ - death or senescence of plant) (A, D: S. Maharjan; B, C, E: BB Shrestha). Fig. S2. Microscopic image of urediniospores of Puccinia abrupta var. partheniicola stained in cotton blue
} 


\section{Acknowledgements}

We are thankful to Mr. Mahesh Raj Bist for his help during the fieldwork and the Department of Plant Resources for providing necessary lab facilities. We would like to thank Ms. Sara Hendery for editing the language of this manuscript.

\section{Authors' contributions}

BBS and PKJ conceptualized and designed the research. AD and PKJ supervised the research. CBB guided the data analysis. SM collected and analyzed the data and wrote the manuscript. AD, BBS, CBB, MR, and PKJ critically commented and approved the final version of the manuscript. The authors read and approved the final version of the manuscript.

\section{Funding}

This research was supported by the United States Agency for International Development (USAID) Bureau of Food Security under the Cooperative Agreement No. AID-OAA-L-15-00001 as part of the Feed the Future Innovation Lab for Integrated Pest Management.

\section{Availability of data and materials}

All data involved in this study are available from the corresponding authors upon request.

\section{Ethics approval and consent to participate}

Not applicable

\section{Consent for publication}

Not applicable

\section{Competing interests}

The authors declare that they have no competing interests.

\section{Author details}

${ }^{1}$ Central Department of Botany, Tribhuvan University, Kathmandu, Nepal. ${ }^{2}$ Department of Plant Resources, Ministry of Forests and Environment, Kathmandu, Nepal. ${ }^{3}$ IPM Innovation Lab, Virginia Tech, Blacksburg, USA.

Received: 27 August 2020 Accepted: 2 October 2020

Published online: 21 October 2020

\section{References}

Adhikari YP, Fischer A, Fischer HS. Micro-site conditions of epiphytic orchids in a human impact gradient in Kathmandu Valley. Nepal. J. Mt. Sci. 2012;9:331-42. https://doi.org/10.1007/s11629-009-2262-1.

Adkin S, Shabbir A, Dhileepan K. Parthenium weed: biology, ecology and management: CAB International; 2019.

Adkins S, Shabbir A. Biology, ecology and management of the invasive parthenium weed (Parthenium hysterophorus L.). Pest Manag. Sci. 2014;70: 1023-9. https://doi.org/10.1002/ps.3708.

Bekeko Z, Hussien T, Tessema T. Distribution, incidence, severity and effect of the rust (Puccinia abrupta var. partheniicola) on Parthenium hysterophorus L. in Western Hararghe Zone, Ethiopia. African J. Plant Sci. 2012;6:37-345. https://doi.org/10.5897/ajps12.040.

Charudattan R. Biological control of weeds by means of plant pathogens: significance for integrated weed management in modern agro-ecology. BioControl. 2001:46:229-60. https://doi.org/10.1023/A:1011477531101.

Charudattan R, Dinoor A. Biological control of weeds using plant pathogens: accomplishments and limitations. Crop Prot. 2000;19:691-695. https:/doi.org/ 10.1016/S0261-2194(00)00092-2.

Dhileepan K, McFadyen RC. Parthenium hysterophorus L. - parthenium. In: Julien, M., McFadyen RE, Cullen J. (Editors), Biological control of weeds in Australia: 1962 to 2010. CSIRO Publishing, Melbourne, Vic.; 2012:pp448-463. https://doi. org/10.1097/00000441-189708000-00016.

Dhileepan K, McFadyen RC, Strathie LW, Khan N. 2019. Biological control. In: Adkins S, Shabbir A, Dhileepan K. (Editors), Parthenium weed: biology, ecology and management. CAB International;2019:pp131-156.

Dhileepan K, Strathie LW. Parthenium hysterophorus L. (Asteraceae). In: Muniappan R, Reddy GVP, Raman A. (Editors), Biological control of tropical weeds using arthropods. cambridge University Press; 2009:pp274-318.

DHM. Climatological records of Nepal. Department of Hydrology and Meterology. Kathmandu: Government of Nepal; 2016.
Evans HC. Life cycle of Puccinia abrupta var. partheniicola, A potential biological control agent of Parthenium hysterophorus. Trans. Br. Mycol. Soc. 1987:88:105-111. https://doi.org/10.1016/50007-1536(87)80191-2.

Evans HC. Parthenium hysterophorus: A review of its weed status and the possibilities for biological control. Biocontrol News and Information. 1997;18: $89 \mathrm{~N}-98 \mathrm{~N}$.

Fauzi MT. Biocontrol ability of Puccinia abrupta var. partheniicola on different growth stages of parthenium weed (Parthenium hysterophorus L.). Hayati J. Biosci. 2009;16:83-7. https://doi.org/10.4308/hjb.16.3.83.

French BW, Reitsma KD, Beckler AA, Chandler D, Clay SA. Geographic information systems in corn rootworm management. In: Clay SA (Editor), GIS applications in agriculture volume three: invasive species. Taylor and Francis group;2011: 233-253.

lqbal IM, Ali K, Evans HC, Rehman A, Seier MK, Shabbir A, Weyl P. The first record of Puccinia abrupta var. partheniicola, on Parthenium hysterophorus an invasive alien plant species in Pakistan. Biolnvasions Rec. 2020;9:1-7. https://doi.org/10.3391/bir.2020.9.1.01.

Maharjan S, Shrestha BB, Devkota A, Muniappan R, Jha PK. Temporal and spatial patterns of research on a globally significant invasive weed Parthenium hysterophorus L.: A bibliographic review. Crop Prot. 2020;135:104832. https://doi.org/10.1016/j.cropro.2019.05.026.

McFadyen RC. Biological control of weeds. Annu. Rev. Entomol. 1998;43:369-93.

Pant PR, Dangol D. Kathmandu Valley profile, briefing paper: governance and infrastructure development challenges in the Kathmandu Valley. Workshop: 11-13 February 2009, Kathmandu Metropolitan City, Nepal. 2009:p 15.

Parker A, Holden ANG, Tomley AJ. Host specificity testing and assessment of the pathogenicity of the rust, Puccinia abrupta var. partheniicola, as a biological control agent of parthenium weed (Parthenium hysterophorus). Plant Pathol. 1994;43:1-16. https://doi.org/10.1111/j.1365-3059.1994.tb00547.x.

Parmelee JA. The autoecious species of Puccinia on Heliantheae in North America. Can. J. Bot. 1967;45:2267-327. https://doi.org/10.1139/b67-248.

Pokhrel K. Invasiveness of Parthenium hysterophorus L.: phenology and response to clipping. M. Sc. thesis, Central Department of Botany, Tribhuvan University, Kathmandu, Nepal; 2013.

R Core Team. R: a language and environment for statistical computing. A Lang. Environ. Stat. Comput. R Found. Stat. Comput. Vienna, Austria; 2019.

Seastedt TR. Biological control of invasive plant species: a reassessment for the Anthropocene. New Phytol. 2015;205:490-502. https:/doi.org/10.1111/nph.13065.

Shrestha BB. Puccinia abrupta var. partheniicola: A biocontrol agent of Parthenium hysterophorus new to Nepal. Biocontrol News and Information. 2012;33:2 N. https://doi.org/10.1177/107755874500200523.

Shrestha BB, Shabbir A, Adkins S. Parthenium hysterophorus in Nepal: a review of its weed status and possibilities for management. Weed Res. 2015;55:132-44. https://doi.org/10.1111/wre.12133.

Strathie LW, Den Breeyen A, Sambo S, Chidawanyike F, Gareeb M. Recent developments in the management of the invasive plant Parthenium hysterophorus using natural enemies. Proc. S. Afr. Sug. Technol. Ass. 2016;89:307-13.

Strathie LW, McConnachie A, Retief E. Initiation of biological control against Parthenium hysterophorus L. (Asteraceae) in South Africa. African Entomol. 2011;19:378-92. https://doi.org/10.4001/003.019.0224.

Taye T. Investigation of pathogens for biological control of parthenium (Parthenium hysterophorus L.) in Ethiopia. Humboldt Universitat zu Berlin; 2002.

Taye T, Gossmann M, Einhorn G, Buttner C, Metz R, Abate D. The potential of pathogens as biological control of parthenium weed (Parthenium hysterophorus L.) in Ethiopia. Mededelingen (Rijksuniversiteit te Gent. Fakulteit van de Landbouwkundige en Toegepaste Biologische Wetenschappen). 2002;67:409-20.

Timsina B, Shrestha BB, Rokaya M, Münzbergová Z. Impact of Parthenium hysterophorus L. invasion on plant species composition and soil properties of grassland communities in Nepal. Flora. 2011;206:233-40. https://doi.org/10. 1016/j.flora.2010.09.004

\section{Publisher's Note}

Springer Nature remains neutral with regard to jurisdictional claims in published maps and institutional affiliations. 